\title{
Aquinas on Continuity and Identity
}

\section{CHRISTOPHER HUGHES}

\author{
King's College
}

In what follows, I shall argue that there is a difficulty in fitting together Aquinas's general account of the individuation of substances and their forms with his account of identity through time. Aquinas's account of individuation entails that a certain condition is sufficient for identity. His account of identity through time entails that various other conditions are necessary for identity. If the first condition really is sufficient for identity, and the others really are necessary, then no pair of things can satisfy the first condition, without satisfying all the others. But, I shall show that there are pairs of things that satisfy the first condition, without satisfying the others.

Consider the following principle:

(PID) If two things are the same kind of thing, they are the same thing, unless they are (or were) in different subjects, or are made of different bits of matter. ${ }^{1}$

("PID" stands for "principle of intra-specific difference")

What would Aquinas say about (PID)? Although he does not, to my knowledge, explicitly endorse it, I will argue by cases that he is committed to it.

Suppose $\mathrm{a}$ and $\mathrm{b}$ are numerically different predicamental accidents of the same kind-say, two different whitenesses. In what other ways will a and $\mathrm{b}$ differ? We may see how Aquinas would answer this question by consider-

Thanks to Norman Kretzmann, John Haldane, and Marcia Mayeda.

1. By "the same kind of thing" I mean "the same non-generic kind of thing." To put it another way, by "the same kind of thing" I mean what Aquinas means by "idem specie," when he is using "species" broadly enough that not just two substances, but also two forms, or two matters, may be described as idem specie. For this broad use of "species", see e.g., De Principiis Naturae (DPN), and De Spiritualibus Creaturis (DSC) un., 3, ad 19um). 
ing the first part of his central argument for the claim that angels are one of a kind:

If an angel is a simple form apart from matter, it is impossible to even conceive that there are several angels of one species, because any form, however material and low, if considered as separate . . . remains the only one of its kind. So if whiteness is understood as subsisting without any subject, it will not be possible to posit many whitenesses; for we see that this whiteness does not differ from that whiteness except insofar as it is in this subject or that subject. ${ }^{2}$

If (as we have said) angels are not composed of matter and form, it is impossible for there to be two angels in the same species, just as it would be impossible for there to be many whitenesses, or many humanities, since whitenesses are not many, except insofar as they are in many subjects. ${ }^{3}$

In each of these passages, Aquinas appears to conclude that different accidental forms of the same kind must be in different subjects. Indeed, he seems to draw the stronger conclusion that different forms of the same kind (whether they are accidental forms, such as whitenesses, or substantial forms, such as humanities) must be in different subjects. ${ }^{4}$ Moreover, Aquinas apparently thinks that esses (existences) of the same kind cannot differ unless they are in different subjects. For he says at Summa Contra Gentiles II, 52:

If . . e esse is common in the way a genus is, a separate and per se subsistent esse can be one only. But if-as is actually the case-it is not divided by differences, the way a genus is, but by the fact that it is the esse of this or that, then it is even more manifest that there can be but one esse existing per se.

2. DSC un. 8, responsio.

3. ST Ia, 50, 4, responsio; also see ST Ia, 75, 7 responsio.

4. Here I am using "subject" broadly enough that both accidental forms and substantial forms may be said to be in a subject. Aquinas thinks that, in a narrow sense of "subject", accidental forms are in a subject, but substantial forms are not: "Because the nature of an accident is to be in a subject-where by a subject is understood some actual being, and not a merely potential one-in that sense a substantial form is not in a subject, but in matter" (DSC un. 3, responsio).

But he also recognizes a broader sense of "subject" on which both accidental and (material) substantial forms are in a subject: "Any form incapable of being multiplied by specific differences cannot be multiplied at all, unless it is a form that exists in a subject" (Compendium Theologiae (CT) 15).

If in this passage, Aquinas were using "subject" in its narrow sense (according to which no substantial form is in a subject), he would be saying that no specific substantial form can be multiplied. Since he obviously does not hold that view, he must be using "subject" broadly enough to cover what substantial forms are in (bits of matter), as well as what accidental forms are in (individual substances). 
This esse cannot be different from that esse, unless this esse is the esse of (or in) this being, and that esse is the esse, of (or in) that (distinct) being.

In the passage just cited, Aquinas seems to be focusing on what he calls substantial, as opposed to accidental, esse. The substantial esse of a substance is that in virtue of which that substance has being simpliciter; and one and the same substance cannot have two different substantial esses, since it cannot "be" simpliciter, twice over. ${ }^{5}$ An accidental esse of a substance is that in virtue of which that substance has a particular kind of being-for instance, being white, or being musical-and one and the same substance can have many different accidental esses, since it can be many different ways (white, musical, and so on). ${ }^{6}$ Different substantial esses must be in different subjects, but different accidental esses need not be. Nevertheless, Aquinas would say, different accidental esses of the same (most determinate) kind-different being-white-s, or different being-musical-s-must be in different subjects.

So we might conclude that, for Aquinas, forms or esses of the same kind are identical unless they are in different subjects. But once we consider Aquinas's views on the sacrament of the Eucharist and the incorruptibility of the soul, we can see that this is not so. Aquinas thinks that, in the sacrament of the Eucharist, an accident of dimensive quantity conserves its existence and particular identity, even after it has ceased to be in the bread, or anything else. ${ }^{7}$ This entails that if two duplicate bits of bread are consecrated, two conspecific unreceived quantitative accidents will remain. So Aquinas presumably does not think that different conspecific accidental forms are always in different subjects. And he clearly does not hold that different conspecific substantial forms are always in different subjects, since he thinks both that souls are substantial forms, and that Peter's soul and Martin's soul conserve their existence and particular identity after disembodiment, when they are no longer in anything at all. What Aquinas does seem to hold is that different conspecific (accidental or substantial) forms must be in, or have been in, different subjects. As he thinks of it, even though this non-species-exhausting form can go on being the particular form it is, without still being in its original subject (or in any subject at all), the only way such a form can (originally)

5. See Summa Theologiae (ST) IIIa, 17, 2: "Illud esse quod pertinet ad ipsam hypostasim vel personam secundum se, impossibile est in una hypostasi vel persona multiplicari: quia impossibile est quod unius rei non sit unum esse."

6. Si aliqua forma vel natura est quae non pertineat ad esse personale hypostasis subsistentis, illud esse non dicitur esse illius personae simpliciter, sed secundum quid: "sicut esse album est esse Socratis, non inquantum est Sorates, sed inquantum est albus. Et huiusmodi esse nihil prohibet multiplicari in una hypostasi vel persona: aliud enim est esse quo Socrates est albus, et quo Socrates est musicus" (ST IIIa, 17, 2).

7. ST IIIa, 77, 1, 3 and ad 3um. 
get to be the particular form it is, is by (originally) being in that (original) subject. ${ }^{8}$

In short, for Aquinas, (a) any two forms of the same kind, or esses of the same kind, are identical, if they are not, and never were, in different subjects. So, for Aquinas, (b) any two forms of the same kind, or esses of the same kind, are identical, if they are not, and never were, in different subjects, and they are not made of different matters. (Aquinas would regard [b] as having the same truth-value as [a], inasmuch as forms or esses are never made of matter). In other words, any two forms of the same kind, or esses of the same kind, are identical, unless they are or were in different subjects, or they are made of different matters. That is to say, for Aquinas, any pair of esses, or pair of forms, satisfies the condition that (PID) says every pair of things satisfies. (For brevity, I shall henceforth say that pairs of things satisfy [PID], rather than that pairs of things satisfy the condition [PID] says every pair of things satisfies.)

Will every pair of substances satisfy (PID)? On Aquinas's account, if two substances are substances of the same kind, it must be that both are material, or that both are immaterial. Moreover, if two immaterial substances are substances of the same kind, they must both be complete immaterial substances (like the angels), or both be incomplete immaterial substances (like human souls). ${ }^{9}$ Incomplete immaterial substances are forms, and, as we have already seen, for Aquinas, any pair of forms satisfies (PID). So, for Aquinas, any pair of incomplete immaterial substances satisfies (PID). What about any pair of complete immaterial substances - that is, any pair of angels? A brief answer is as follows: in various places Aquinas avers that angels are forms. ${ }^{10}$ If angels are forms, and forms satisfy (PID), then angels satisfy (PID).

The brief answer may be too brief. Although Aquinas does say that angels are forms, he also makes statements that seem to preclude the identification of an angel with any form. He clearly holds that an angel is

8. See ST, IIIa, 77, 1, ad 3um, for Aquinas's discussion of accidents' original dependence on, and subsequent independence from, their subjects. Aquinas makes the same point concerning the substantial form which is the soul at ST Ia, 76, 2, ad 2um; and at De Ente et Essentia 5: "Individuatio animarum et multitudo dependet ex corpore quantum ad sui principium sed non quantum ad sui finem."

9. For Aquinas, even though a human soul is (at least originally) a form in matter, it is also a substance, because-unlike any other form in matter-it has its own esse and its own operation. (See DSC un. 2, responsio; and ST Ia, 75, 2). On the other hand, Aquinas would deny that the human soul is a complete substance, the way a man or an angel is: otherwise the soul, like a man or an angel, would fall under a species and genus, rather than just being the formal part of something (a man) which falls under a species and genus (cf. Summa Contra Gentiles (SCG) II, 94). It follows that human souls are not the same kind of thing as angels.

10. For instance, at DSC un. 5, ad 10um, and ST Ia, 56, 2, ad 3um: "Ipse angelus est forma subsistens in esse naturali." 
composed of essence and accidents, and likewise of essence and esse. ${ }^{11}$ If, however, an angel is composed of essence and accidents, and essence and esse, it is hard to see how he-as opposed to his nature-can be a form. A substantial form includes only what belongs to a thing's essence; an accidental form includes only what is outside of a thing's essence. ${ }^{12}$ So if an angel is a form, then-since that angel "includes" (is composed of) both essence and accidents-it would seem that some form is neither purely substantial nor purely accidental. I do not know of any place where Aquinas recognizes the existence of forms that are, as it were, in part substantial and in part accidental; furthermore, I doubt he would happy to countenance such things.

Even if we presume that angels have no matter, there seem to be Thomistic reasons to doubt whether they are forms. Regardless of whether they are, or are not forms, Aquinas insists in a number of places that angels of the same kind are identical. ${ }^{13}$ And he thinks that angels are not in a subject, and not made of matter. ${ }^{14}$ So Aquinas would agree that angels of the same kind are identical unless they are or were in different subjects or made of different matters. Hence angels will, for Aquinas satisfy (PID).

Aquinas would also say that any two material substances satisfy (PID). This comes out clearly, in Aquinas's dilemmatic argument for the claim that conspecific angels are identical. Aquinas begins by supposing that either angels have matter, or do not have matter. If angels have no matter, then the specific essence of any angel will be a substantial form whose nature it is to subsist apart from any subject. As we have seen, Aquinas holds that such forms are immultipliable. So if angels are free from matter, he concludes, then conspecific angels are identical. But, Aquinas goes on to say, even if angels have a kind of "spiritual matter," it will still be true that conspecific angels are identical:

If an angel is a substance composed of form and matter, it is necessary to say that the matters of different angels are in some way distinct. There are only two kinds of distinction between matter and matter. One is according to the proper nature of matter, according to its relation to different acts. . . . In this way the matter of inferior bodies, which is a potency towards esse, differs from the matter of celestial bodies, which is a potency towards place. The second kind of distinction of matter, though, is according to quantity, inasmuch as matter

11. For composition of essence and esse in angels, see In II Sentences d. 3, 1, 1; Quodlibetum (Quod.) 2, 2, 1, and SCG II, 52; for composition of essence and accidents in angels, see Quod. 2, 2, 2, and De Unione Verbi Incarnati un., 1, responsio.

12. At Quod. 12, 5, 1, Aquinas says that an accident, in the broadest sense, is whatever is not part of an essence.

13. See DSC un., 8, responsio; ST Ia, 50, 4, responsio; SCG II, 93; CT 77, and so on.

14. See DSC un., 1, responsio; and ST Ia, 50, 2, for the immateriality of angels; see DSC un., 8 ad 4, and 5, obj. 8 and $a d 8$ um for the "un-received-ness" of angels. 
existing under these dimensions is distinguished from matter existing under other dimensions. Now the first kind of distinction between matters gives rise to generic difference ... while the second kind of distinction between matters gives rise to intra-specific difference. This second kind of distinction between matters cannot be found in different angels, since they are incorporeal, and completely without quantitative dimensions. . . . So if there are different angels composed of matter and form ... there is the first kind of distinction between their matters . . . and they differ not just in species, but also in genus. ${ }^{15}$

For our purposes, the key premise in this argument is the first one-that if angels are material, different angels must have different matters. Aquinas considers himself entitled to this premise, because he holds that different material substances-whether of the same kind, or of different kinds-are always made of different matters. Thus Aquinas would agree that two material substances of the same kind are identical, (a) unless they are made of different matters, and (b) unless they are made of different matters or are or were in different subjects. (For Aquinas, material substances are never received in different subjects, so (a) and (b) amount to the same thing.) In other words, Aquinas would agree that any two material substances, like any two immaterial substances, satisfy (PID). Finally, for reasons which I need not set out explicitly, Aquinas would agree that any two matters satisfy (PID).

Now, for Aquinas, anything that is, is a substance, a substantial form, a bit of matter, a predicamental accident, or an esse. So, on Aquinas's account, for any two things, there will either be (at least) one of those ontological categories both of those things fall under, or there will not be. If there is not, those two things will trivially satisfy (PID), in virtue of not being things of the same kind. (Any two things that differ categorially differ specifically.) If there is at least one category that those two things fall under, then-it has been the burden of this section to show-they will, for Aquinas, non-trivially satisfy (PID). So, for Aquinas, any pair of things satisfies the condition that (PID) says every pair of things satisfies. Thus Aquinas is committed to (PID).

\section{II}

At Summa Contra Gentiles IV, 80, Aquinas sets out a number of interrelated objections to the doctrine of the resurrection, the first two of which may be summarized as follows:

(1) Once things have undergone corruption, they cannot come back into existence. At death a man undergoes corruption; so he cannot come back to life.

15. DSC un. 8, responsio; see also ST Ia, 50, 4 responsio. 
(2) If things entirely return to nothingness, they cannot come back. But various essential principles of a man entirely return to nothingness when he goes out of existence-his corporeity, parts of his sensitive and nutritive souls, and his humanity. Since those essential principles of a man cannot come back, neither can he.

Aquinas responds to these objections as follows:

(1) The very thing that was corrupted cannot be restored through the operation of nature ... . But, since God's power remains the same, even when things are corrupted, it can restore what has been corrupted to integrity. 16

(2) None of the essential principles of a man yields entirely to nothingness in death: the rational soul, which is the form of a man, remains after death ... and the matter that was the subject of such a form also remains, under those dimensions in virtue of which it was that individual matter. ${ }^{17}$

It is clear from Aquinas's response to the first objection that he accepts the following principle:

(C1) Necessarily, in the course of nature: if a and b are identical, and if a exists at time $t$, and $b$ exists at time $t^{\prime}$, then $a$ is not corrupted between $\mathrm{t}$ and $\mathrm{t}^{\prime}$.

("C" stands for continuity).

Note the modality of (C1): although Aquinas does not think it is necessarily (or even contingently) true that nothing corrupted comes back, he does think it is necessary that, in the course of nature, nothing corrupted comes back. ${ }^{18}$

Aquinas responds to the second objection by arguing that (all) the essential principles of man survive his death. He does not take issue with the claim that if any of the principles of a thing's essence (entirely) ceased to exist, that thing could never exist again. Nor is Aquinas simply leaving the claim unchallenged for the sake of argument, as is clear from Aquinas's response to a different objection to the resurrection in the Commentary on the Sentences. ${ }^{19}$ The objection goes like this: if a post-mortem man were numerically identical to an ante-mortem man, the post-mortem man's (post-mortem) senses would have to be numerically identical to the antemortem man's (ante-mortem) senses. But the post-mortem senses cannot be numerically identical to the ante-mortem senses, because the ante-mor-

16. SCG IV, 81 .

17. SCG IV, 81.

18. Aquinas also asserts (C1) at CT 154; and in the Commentary on the Sentences IV, 1, 1, 1, where he invokes the authority of Aristotle.

19. Commentary on the Sentences IV, d. 44, 1, 1, obj. 3. 
tem senses go out of existence when the man dies, and once they are gone, they are gone forever. Aquinas answers that whether or not we should say that the ante-mortem man's senses go out of existence when he dies, depends on what we mean by "his senses." The ante-mortem sense powers go out of existence at death. But since these are accidental properties (accidentales proprietates), their demise does not preclude the subsequent post-mortem existence of the man. On the other hand, the (ante-mortem) man's sensitive soul does not go out of existence, because it is identical to that man's rational soul, and the man's rational soul survives his death. This way of answering the objection, Aquinas notes, is unavailable to someone who holds that a man's sensitive soul is distinct from his rational soul. Someone who holds that view, Aquinas says, would have to concede that, since the (ante-mortem) man's sensitive soul goes out of existence when he dies, no post-mortem man is numerically the same as any ante-mortem man. ${ }^{20}$ Here Aquinas seems to be reasoning along these lines: if the sensitive soul were distinct from the rational soul, it would be an essential principle of a man that ceases to exist at his death, and never comes back. But a man cannot come back unless all of his essential principles do. So if the sensitive soul were distinct from the rational soul, no man could come back from the dead.

It appears, then, that Aquinas accepts:

(C2) Necessarily, if a and b are identical, then if a exists at time t, and $b$ exists at time $t^{\prime}$, (not just some, but all) the essential principles of a exist at every time between $t$ and $t^{\prime}$.

If (C2) is true, this suggests that only (metaphysically) composite things can come back into existence. For simple things do not have essences constituted of (simpler) essential principles which can go on existing when the whole essence of which they were parts no longer exists. In particular, it would seem that if (C2) is true, accidental forms, substantial forms, and esses cannot come back into existence.

And in fact, in Summa Contra Gentiles IV, 81, Aquinas seems not to say that a man's substantial form, or his (substantial) esse, or any of his accidents come back into existence. He says that a man's form and esse never go out of existence; and although he says that a man's (ante-mortem) corporeity, construed as an accident, does go out of existence when the man dies, he doesn't say that that very accident ever returns. Indeed, at Compendium

20. "Ad tertium dicendum, quod ratio illa optime concludit contra illos qui ponebant animam sensibilem et rationem diversas in homine esse, quia secundum hoc anima sensitiva in homine non esset incorruptibilis, sicut nec in aliis animalibus: unde in resurrectione non esset eadem anima sensibilis, et per consequens nec idem animal, nec idem homo." (Commentary on the Sentences IV, 44, 1,1 ad 3um). 
Theologiae 154, Aquinas says that even though a man's ante-mortem corporeity, construed as an accident, is not recovered after his death,

the identity of the subject is not for this reason impeded, since the unity of the essential principles suffices for this. The same goes for all the accidents, the diversity of which does not destroy numerical identity.

Now Aquinas shows no signs of holding the unattractive view that accidents cannot come back from nothingness, but substantial forms or esses can. So it would seem that Aquinas accepts:

(C3) Necessarily: if a and b are forms or esses, and a and b are identical, then a exists at time $\mathrm{t}$, and $\mathrm{b}$ exists at time $\mathrm{t}^{\prime}$, only if a exists at every time between $t$ and $t^{\prime}$.

Now, it is very hard to see how Aquinas can consistently hold both (PID) and (C1)-(C3). As we have seen, for Aquinas a man can come back from the dead, because when he dies neither of the principles or parts of his essence will perish: his substantial form (that is, his currently rational and once and futurely sensitive soul) will survive, and likewise his matter. As Aquinas puts it at Compendium Theologiae 154:

Since all things, even the very least, fall under God's providence ... the matter composing this human body, whatever form it may take after a man's death, evidently does not elude the power or knowledge of God. Such matter remains numerically the same, in the sense that it exists under quantitative dimensions, in virtue of which it can be said to be this particular matter, and is the principle of individuation. ${ }^{21}$

Now if the matter of a man will still exist-albeit under another form-after his death, then the matter of say, a bit of fire, should also exist-under another form-after the fire (and its [non-subsistent] substantial form) have gone out of existence. When the fire undergoes corruption, the fire's matter will take on a substantial form of a different kind. But there is nothing to prevent that bit of matter from taking on at some subsequent time a form of the very same species it lost when the fire went out of existence. Indeed, Aquinas says that from fire is generated air, whence water, whence earth, whence fire. Since this process is natural, it follows from (C1) that when it takes place, the bit of fire that originally went out of existence (when its matter became aeriform) is specifically the same as, but numerically different from, the bit of fire that subsequently came into existence (when its matter became igniform). (It also follows from [C2], given the ancillary premiss that when some fire perishes, so does one of its

21. For further discussion of individual matter and its dimensions, see the Commentary on the Sentences IV, d. 44, 1, 1, ad 3um; and Quod. 11, 6, 2, and ad 2um. 
essential principles-its igneous form.) ${ }^{22}$ That is in fact what Aquinas says about this case in Commentary on the Sentences IV, d. 44, 1, 1, ad 1um. If, however, two numerically distinct fires are made of the same matter, (PID) is false. Two things of the same kind-the original and subsequent fires-will differ, without either being made of different matter, or being in different subjects. Moreover, two (igneous) substantial forms will differ without either being made of different matter, or being in different subjects. If the igneous form that went out of existence were the same as the igneous form that came into existence, then two numerically distinct fires would have all the same essential principles (that is, the same matter, and the same form). But if they had all the same essential principles, they would have the same essence, and be the same fire: (numerically) different things cannot have (numerically) the same essence.

So it looks as though we can get from (C1) or (C2) (and ancillary premisses Aquinas would find unexceptionable) to the denial of (PID). Some might object here that, although there is a difficulty for Aquinas, the difficulty ultimately concerns his account of the resurrection, rather than his general views on identity and identity through time. In explaining how the resurrection is possible, Aquinas says that the individual matter that partly constitutes a man's individual essence, and is the principle of individuation for the man and his substantial form, is a bit of matter under certain dimensions. ${ }^{23}$ But, as I have argued elsewhere, when the resurrection is not under discussion, Aquinas says that the individual matter that partly constitutes a man's individual essence, and individuates both that man and his form, is this flesh and these bones, or this body. ${ }^{24}$ Now it does not look as though Aquinas's matter-under-these-dimensions ( Compendium Theologiae 154) could be the same thing, under a different description, as this flesh and these bones (or this body). To start with, the matter-under-these-dimensions of Socrates is still with us, even though it is no longer Socratically informed. (If it were no longer with us, it would not help Aquinas explain how Socrates will come back, given that nothing can come back, once its essential principles have perished). As Aquinas would agree, though, Socrates' flesh and bones, and his body, are no longer with us. ${ }^{25}$ Moreover, Aquinas clearly thinks that Socrates' body, and his flesh and bones, undergo compositional change over time, as bits of

22. That Aquinas accepts this ancillary premiss is clear from the Commentary on the Sentences IV, d. 44, 1, 1, ad 1um: "aliorum generabilium et corruptibilium forma non est per se subsistens, ut post compositi corruptionem remanere valeat, sicut est de anima rationali."

23. SCG IV, 81; and CT 154.

24. See, e.g., Summa Theologiae, Ia, 75, 4, responsio, and Ia, 119, 1, responsio, For more details, see my "Matter and Individuation in Aquinas", History of Philosophy Quarterly vol. 13, no. 1 (1996), pp. 1-16.

25. When Socrates died, he left behind a dead body; and no dead body is identical to any living body. See Summa Theologiae, IIIa, 50, 5, and Quodlibetum 2. 1.1 . 
matter that used to be the matter of Socrates' dinner become the matter of Socrates' flesh and bones. ${ }^{26}$ Flesh and bones are a kind of matter, but a kind of matter that has a matter of its own; moreover, it has different matters at different times, and accordingly remains in the same man $s e-$ cundum speciem, but not secundum materiam. The same presumably cannot be said for the matter-under-these-dimensions: it does not have a principle whereby it could conserve its numerical identity through compositional change.

To recap: suppose, as Aquinas does, that the principles of Socrates' essence are a bit of matter and a substantial form, and that (C2) is true. Then Socrates will rise from the dead only if there is some matter that (a) will exist at every time between his death and his resurrection, and (b) was and once again will be a principle of Socrates' essence. Such matter would have to both survive and individuate Socrates. The difficulty for Aquinas is that although, on his account, both individuating matter and surviving matter exist in Socrates, the individuating matter does not seem to survive, and the surviving matter does not seem to individuate.

Suppose, though, Aquinas had not wanted to make room for the resurrection of the dead. On the face of it, he could then have maintained both that (i) once either the material or the formal principle of Socrates' essence goes, Socrates is gone forever, and (ii) different men-whether existing at the same time, or at different times-always have different matters (different flesh and bones, different bodies). More generally, if he had held that the matter that is an essential principle never survives, he could have maintained both that different substances of the same kind always have different matters, and that things any of whose essential principles go out of existence cannot come back. So, it might be thought, Aquinas could square (PID) with (C2) - and, more generally, with (C1)-(C3) - even if he cannot square the the combination of all those views with the doctrine of the resurrection.

I do not think this is right. Aquinas thinks a subject can lose an accident, and later acquire an accident of that same kind. As we have seen, this will happen on Aquinas's account of the resurrection: after his death, Socrates will acquire sense-powers of the same kind as the ones he lost when he died. But, for Aquinas, it can and sometimes does happen in cases where the subject of the accidents does not go out of and come back into existence. A healthy man may lose his health (without losing his life), and later acquire health. ${ }^{27}$ Also, a bit of bronze that had a certain shape, will lose its shape, and acquire a different kind of shape, when the statue it constitutes is melted down. But the bronze will subsequently acquire a shape of just the same kind as it had previously, if the liquid bronze is poured back into the

26. Cf. Summa Theologiae, Ia, 119, 1, responsio and ad 2um; Quodlibetum 8, 3, 1, and Summa Contra Gentiles, IV, 81.

27. SCG IV, 81. 
mold in which the original statue was made. ${ }^{28}$ In both of these cases, we have perfectly natural, non-miraculous events; moreover, both involve the corruption of an accident. (For Aquinas, an accident is [directly] corrupted when it is replaced by an incompatible accident.) ${ }^{29}$ So if $(\mathrm{C} 1)$ is true, the health the man has after he recovers, or the shape the bronze has after it is recast, will be specifically identical to, but numerically distinct from, the health the man had before he fell ill, or the shape the bronze had before it was melted down. This is just what (PID) rules out. That the two healths, or two shapes, are specifically identical but numerically distinct accidents in the same subject, also follows from (C2), since accidents are not composite enough to have essential principles which outlast them, and from (C3), which says that accidents cannot come back.

Moreover, Aquinas holds that God can, and did, make angels exist after not existing. ${ }^{30}$ And he holds that God could make an angel not exist, after existing-although $\mathrm{He}$ in fact never does. ${ }^{31}$ So God could bring it about (and has brought it about) that (i) first there is no angel of a certain species, and then there is. And He could bring it about that (ii) first there is an angel of a certain species, and then there is not. In that case, it is surely not beyond God's power to bring it about that: (iii) first there is an angel of a certain species, and then there is no angel of that species, and then there is once again an angel of that species. If He did, then, assuming that (C2) is true, the angel that stopped existing earlier would have to be specifically the same as, but numerically different from, the angel that started existing later (since the angel's essence has no essential principle simpler than itself that could survive the angel's demise).

Now it does not follow from (C2), and the premiss that God could make (iii) true, that (PID) is false. All that follows is that (PID) could be false. In fact, though, Aquinas seems to regard (PID) as a necessary truth. As we have seen, he says at Summa Theologiae Ia, 50, 4, responsio, that it is impossible for there to be a plurality of unreceived whitenesses, or humanities, or conspecific angels; and there are many other passages in which Aquinas asserts the impossibility of things differing, without differing with respect to their (original) subject or their matter. ${ }^{32}$ So Aquinas is apparently committed to the necessitation of (PID), and we can get from (C2), and the

28. Aquinas dicusses a case of this sort at Summa Theologiae, in the Commentary on the Sentences, IV, d. 44, 1, 2, ad 4um, and Quodlibetum 11, 6, obj. 3 and ad 3um, although it is not clear whether Aquinas has in mind a case where the shape of the recast bronze is the same in species as the shape the bronze had earlier.

29. ST Ia, 89,5 responsio.

30. See ST Ia, 61, 2, obj. 2, and ad 2um: "Omne quod quandoque est, et quandoque non est, subjacet tempori. Sed angelus est supra tempus . . . ergo angelus non quandoque est, et quandoque non est, sed semper. Ad secundum dicendum quod angelus est supra tempus quod est numerus motus caeli, . . . Non est tamen supra tempus quod est numerus successionis esse eius post non esse."

31. See ST Ia, 50, 5 ad 3um.

32. See, for example, ST Ia, 75, 7, responsio; SCG II, 93; and CT 77. 
claim that God could make (iii) true, to the denial of the necessitation of (PID).

It is perhaps worth pointing out that, given (C2) and the premiss that God has the powers to make and unmake angels described above, it may be necessary to give up not just the necessitation of (PID), but also the necessitation of the following (weaker, and, some might say, more plausible) consequence of (PID):

(pid) If two things existing at the same time are the same kind of thing, they are the same thing, unless they are (or were) in different subjects, or are are made of different bits of matter.

Suppose God actually created the angel Gabriel at midnight of the first day, and will keep him in existence forever. Still, God could have annihilated Gabriel at one minute past midnight, and created an angel of Gabriel's species at two minutes past midnight. If God had done that, then, assuming (C2) is true, He would have created two different conspecific angels-Gabriel and a different angel we may call Gabriel*. Now suppose (pid) is necessarily true. Then, although it is possible for Gabriel and

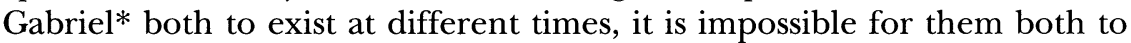
exist at the same time. But there is something very puzzling about this. If God could will that Gabriel come into existence at midnight, that he go out of existence one minute later, and that Gabriel* come into existence at two minutes past midnight, why could He not will just the first and third of those things, and get Gabriel and Gabriel*'s lives to overlap? Someone who, like Aquinas, believed (C2) and the necessitation of (pid) might answer that God cannot will what cannot be the case. But that invites the question: how could it be possible for Gabriel and Gabriel* to exist seriatim, but impossible for them to exist simul?

Suppose that one year I make a statue of a marmot from a certain bit of bronze, and the next year I melt that statue down, and make a statue of a pig from that molten bronze. The two statues do, and a fortiori could, exist at different times. But, it seems, they could not exist at the same time. That is because they compete for existence. The marmot statue can exist only while a certain bit of bronze has a certain shape, and the pig statue can exist only while that same bit of bronze has a different, incompatible shape. So in this case, we can see how two things could be capable of existing at different times, but incapable of existing at the same time. It is clear, though, that Aquinas could not tell anything like this story to explain how it is that Gabriel and Gabriel* can exist at different times, but not at the same time. On his account, no two angels have matter or any other metaphysical constitutents in common. Because Gabriel and Gabriel* do not, as mereologists say, "overlap"-because Gabriel and Gabriel*, though immaterial, are more like two statues of the same kind made of different bits of bronze, than they are like two statues of different kinds made of the same 
bronze-it is very difficult to see how they could be in competition for existence, as they would have to be, were the necessitation of (pid) true.

In summary, even if Aquinas did not want to make room for the resurrection of the dead, he would still have to choose between (PID) and (C1)-(C3). If continuity is necessary for identity, in the ways specified in (C1)-(C3), being in the same subject or made of the same matter is not sufficient for identity, as (PID) says it is.

\section{III}

One reaction to this might be:

So much the worse for (PID). Even if it is true that different material things of the same kind cannot be made of the same matter at the same time, there is no good reason to suppose that different material things of the same kind cannot be made of the same matter at different times. ${ }^{33}$ (C1) on the other hand, is fine, in fact, the stronger principle that results from deleting "in the course of nature" from (C1) is fine. (C2) and (C3) are also perfectly good principles.

By way of conclusion, I want to say why the above seems to me the wrong sort of lesson to draw from the inconsistency of (PID) with (C1)-(C3).

First, Aquinas would agree that, on one way of construing matter, different things of the same kind can be made of the same matter at different times. For, he would grant, the matter which was first the matter of Socrates' dinner, and then the matter of Socrates' flesh and bones (and Socrates) might-long after it had ceased to be the matter of Socrates-become the matter of St. Anselm's flesh and bones (and St. Anselm). But he would say that, on another way of construing matter, it is just as impossible for two different men to have the same matter (the very same flesh and bones, the very same body) at two different times, as it is for two different men to have the same matter at the same time-and likewise for every other kind of material substance. Aquinas might be wrong about this, but he certainly is not obviously wrong.

Second, Aquinas thinks that, in the resurrection, a being that went out of existence (a man) comes back into existence, because some of that being's constitutents (his matter and form) survived his demise, and were later "put back together" in such a way as to bring him back. He accordingly

33. In fact, someone might suggest, perhaps Aquinas never intended to assert (PID); perhaps he intended only to assert something like the weaker (pid). Perhaps; but I have been unable to find textual support for this suggestion. 
thinks that the stronger principle that would result from deleting "in the course of nature" from (C1) is false. For reasons I shall briefly sketch, I think he is right on this last point.

Suppose I bring two qualitatively identical bicycles home from the shop-call them A and B. I then disassemble them completely. Once they are disassembled, I put half of A's parts together with half of B's parts, and the other half of A's parts together with the other half of B's parts. (For the sake of symmetry, let us suppose that the frames of A and B can each be disassembled into two pieces). As a result of this disassembling and subsequent assembling, I have (at least) two bicycles-call them $\mathrm{C}$ and $\mathrm{D}$. Neither C nor D is identical to either A or B. C obviously cannot be the same as both $\mathrm{A}$ and $\mathrm{B}$, since $\mathrm{A}$ and $\mathrm{B}$ are not the same as each other, and nothing can be the same as each of two things that are not the same as each other. Nor can $C$ be the same as A, but not B, or the same as B, but not A. For neither $\mathrm{A}$ nor $\mathrm{B}$ has a better claim than the other to be identical to $\mathrm{C}$. Pari ratione, $\mathrm{D}$ is not identical to either $\mathrm{A}$ or $\mathrm{B}$.

At this point, I disassemble $\mathrm{C}$ and $\mathrm{D}$, and put all the parts that were in A back together, and all the parts that were in B back together, so that everything looks just as it did when I brought the bicycles home from the shop. How many bicycles do I have now? At least two-viz., my (initially disassembled and now reassembled) bicycles A and B. Moreover, I want to say, just two (A and B). How could it be that, simply by swapping parts around, and then putting them back exactly the way they were, I can turn two bicycles into four?

Suppose, though, I subsequently disassemble A and B, again and put half of A's parts together with half of B's parts, and the other half of A's parts together with the other half of B's, just as I did before. Then C and D will come back from non-existence. So both (C1), and the stronger principle that results from deleting "in the course of nature" from (C1), appear not to be true. ${ }^{34}$

Aquinas thought that the principle, once gone, always gone, failed in just one, miraculous case-the resurrection. Even if he was wrong about that, I think he was right to maintain that the principle has, or at any rate could have, counterexamples. Moreover - though considerations of space prevent me from defending this claim-I think he was right to maintain that it would not be beyond God's power to get a dead man back, by putting together the right sort of (surviving) parts in the right sort of way-even if his account of what the relevant (surviving) parts are, and how the "reassembly" would go, is problematic.

34. Although $\mathrm{C}$ and $\mathrm{D}$ go out of existence when I re-assemble A and B, C's and D's parts do not. And in any case I can think of where it seems clear that something goes out of and comes back into existence, not all of that thing's parts go out of existence when it does. I am accordingly inclined to think Aquinas is right to suppose that nothing can come back from total annihilation, and that only composite things can come back from non-existence. 
In sum, Aquinas's account of continuity and identity is not to be faulted because, in the special case of the resurrection, it does not require enough in the way of continuity to ground identity across time. It is, if anything, to be faulted because, in ordinary cases, it requires too much in the way of continuity to ground identity across time. 